\title{
Pemanfaatan Pengindraan Jauh Untuk Identifikasi Pemukiman Kumuh di Kota Bandung
}

\author{
Anisa Dalilah ${ }^{1 *}$ dan Riki Ridwana ${ }^{1}$
}

${ }^{1}$ Universitas Pendidikan Indonesia, Bandung

\author{
A R T I C L E I N F O \\ Article history: \\ Received 05 November \\ 2019 \\ Accepted 23 Desember \\ 2019 \\ Available online 31 \\ Desember 2019 \\ Kata Kunci: \\ Pemukiman Kumuh; \\ Kemiskinan; Urbanisasi; \\ Interpretasi Citra; Survey \\ Lapangan \\ Keywords: \\ Slums; Poverty; \\ Urbanization; Image \\ Interpretation; Groundchek
}

\begin{abstract}
A B S T R A K
Dikota-kota besar termasuk Kota Bandung terdapat wilayah Kumuh. Salah satu penyebab daerah tersebut kumuh disebabkan banyaknya urbanisasi berlebih di daerah tersebut yang bertanda kuatnya gejala kemiskinan. Tujuan dari penelitian ini untuk mengetahui gambaran mengenai pola persebaran pemukiman kumuh di kota bandung, Identifikasi pemukiman kumuh dilakukan dengan cara memanfaatkan pengindraan jauh serta didukung oleh Ground cek ke lapangan untuk memastikannya supaya data yang diperoleh akurat, dengan memperhatikan variable tata letak, ukuran atap, dan kerapatan bangunan. Sedangkan variable lainnya seperti kondisi prasarana lingkungan, kondisi bangunan, dan kepadatan penduduk di peroleh dari survey lapangan serta data sekunder. Dengan menggunakan metode analisis untuk mengetahui pola persebaran pemukiman kumuh dengan menggunakan teknik analisis tetangga terdekat untuk mengetahui jarak pemukiman kumuh terhadap sungai menggunakan Buffer analisis. Sebagian besar pola persebaran pemukiman di kota bandung membentuk pola acak dan cenderung mendekati daerah - daerah pusat kegiatan seperti jasa, perkantoran, dan industri perdagangan.
\end{abstract}

A B S T R A C T

In big cities, including Bandung, there are slums. One of the causes of the slum is due to excessive urbanization in the area, which is marked by intense symptoms of poverty. The purpose of this study is to find a picture of the distribution patterns of slums in Bandung, identification of slums is made by utilizing remote sensing and supported by ground checks to the field to ensure that the data obtained is accurate, taking into layout variables, roof size, and building density. At the same time, other variables such as environmental infrastructure conditions, building conditions, and population density were obtained from field surveys and secondary data. By using analytical methods to determine the distribution patterns of slums using the nearest neighbor analysis technique to determine the distance of slums to rivers using Buffer analysis. Most of the patterns of distribution of settlements in the city of Bandung form a random pattern. They tend to approach the central areas of activity, such as services, offices, and trade industry.

Copyright (c) Universitas Pendidikan Ganesha. All rights reserved.

* Corresponding author.

E-mail addresses: anisadalilah121@gmail.com 


\section{Pendahuluan}

Kota Bandung cukup strategis manakala di kota tersebut tanpa adanya rumah kumuh. Dengan cukup pesatnya perkembangan dan pertumbuhan penduduk mempunyai dampak besar terhadap bidang sosial, ekonomi, fisik lingkungan yang memerlukan sarana prasarana khusus untuk pertumbuhan penduduk. Maksud dari penelitian ini untuk melengkapi kajian tentang permukiman kumuh di kota bandung. Pemukiman kumuh atau bentuk hunian yang tidak berstuktur, tidak tersedianya fasilitas umum (seperti MCK dan air bersih), tidak perpola (seperti jalan dan letak rumahnya tidak beraturan), dan bentuk fisik suatu pemukimnan tersebut tidak layak huni seperti tiap tahunnya terjadi bencana bajir, longsor dan lain sebagainya di pemukiman tersebut (Muhammad \& Sulistyarso, 2016).

Kota menjadi pusat kegiatan dan juga dapat mendapatkan keuntungan yang lebih besar dari pada pedesaan dalam hal perdagangan atau industri. Maka tidak heran bahwa masyarakat pedesaan berpindah dan menetap pada wilayah perkotaan. Wilayah perkotaan mempunyai jumlah penduduk dua kali lipat dibandingkan pedesaan. Sehingga mengakibatkan timbulnya berbagai masalah dalam penataan ruang dan pengadaan untuk pendidikan, pemukiman, perdagangan, kesehatan, keagamaan, rekreasi, olahraga, industri dan lain sebagainya (Christiawan, 2019b). Pada perencanaan tata ruang harus diperhatikan secara khusus karena berkaitan dengan kebutuhan primer atau fisik masyarakat.

Salah satu penyebab kekumuhan tersebut karena urbanisasi atau perpindahan penduduk. Urbanisasi terwujud hanya jika ada tingkat pertumbuhan populasi perkotaan yang lebih tinggi dibandingkan dengan penduduk pedesaan (Christiawan, 2019a). Peningkatan alami dan migrasi adalah komponen utama dari pertumbuhan penduduk di wilayah manapun. Namun, di daerah perkotaan juga berpartisipasi terhadap pertumbuhan popolasi perkotaan, oleh karena itu, populasi perkotaan dari setiap sudut tumbuh dengan cepat dengan migrasi, peningkatan alam, reklasifikasi perubahan batas. Karena pada saat ini pekerjaan seperti petani dan nelayan di desa - desa menurun dan beralih menjadi pegawai industri dan jasa di perkotaan.

Permukiman kumuh dapat di definisikan sebagai wilayah pemukiman yang tidak layak untuk di huni dengan alasan kepadatan penduduk, ventilasi udara kurang menyebabkan pemukiman tersebut pengap, desain bangunan sempit atau pengaturan yang salah jalan. Pemukiman kumuh dapat di definisikan ke dalam empat persepektif (Simon, Adegoke, \& Adewale, 2013). Pertama, kondisi perekonomian masyarakat di bawah pendapatan yang seharusnya. Kedua, lingkungan masyarakat padat penduduk (melebihi 500 orang per Ha). Ketiga, sarana prasarana tidak lengkap dan tidak memenuhi syarat kesehatan dan teknis. Keempat, sangat padatnya penduduk dan ukuran tiap unit rumah berbeda beda dan dibawah standar, dan rumah tiap hunian di bangun diatas tanah milik orang lain atau Negara diluar perundang udangan yang berlaku. Pertumbuhan penduduk yang cepat menyebabkan semakin besarnya kebutuhan ruang untuk tempat tinggal sehingga menyebabkan berkembangnya permukiman tidak terkontrol, terutama permukiman kumuh yang dapat mengakibatkan menurunnya kualitas permukiman, khususnya didaerah perkotaan (Ekatarji, Yunus, \& Rahardjo, 2016).

Faktor utama yang menyebabkan suatu kawasan dikategorikan kumuh adalah terjadinya urbanisasi berlebih dari desa ke kota. sebagai akibat dari perpindahan konflik antar penduduk. Namun menurut pendapat lain dapat terbentuk pemukiman kumuh diakibatkan tanpa adanya tingkat urbanisasi yang sangat cepat, akan tetapi diakibatkan pemerintah tidak memiliki kapasitas dalam mengatasi urbanisasi yang cepat. Menurut Sintiawati, Wesnawa, \& Suditha (2014) terdapat keterkaitan kondisi kumuhnya suatu kawasan pemukiman dengan jumlah penduduk miskin, sehingga strategi penanggulangan kemiskinan merupakan salah satu pendekatan penanggulangan pemukiman kumuh. Adapun ciri-ciri pemukiman dikatakan kumuh diantaranya sebagai berikut: (1) status prekonomian rendah di bawah rata rata, (2) tampilan fisik bangunan yang miskin kontruksi, sehingga banyaknya bangunan - bangunan temporer tidak terawat dan terurus, (3) kebanyakan pendatang yang tinggal dengan cara menyewa, (4) tidak adanya jarak antar bangunan dan juga tidak terrencana, (5) sistem pengelolaan tidak baik, (6) padat penduduk dan (7) kondisi sosial yang buruk, mengakibatkan banyaknya tindakan kejahatan (Isunju, Schwartz, Schouten, Johnson, \& van Dijk, 2011). 
Ketidak-terkaitannya antara penerapan atau implemantasi dalam pengetahuan menjadi salah satu penyebab utama terjadinya rumah kumuh di kota bandung. dapat diartikan terdapatnya krisis pemahaman masyarakat terhadap penerapan program atau kegiatan penataan ruang kota bandung. Oleh karena itu pemukiman kumuh dicirikan dengan keburukan yang sangat berlebihan karena kurang sehatnya kondisi lingkungan, kurangnya fasilitas umum karena dengan kurangnya fasilitas menimbulkan bahaya untuk masyarakat contohnya fasilitas kesehatan. Pemukiman kumuh dibagi menjadi tiga berdasarkan asal muasalnya. Pertama, wilayah kumuh dilihat dari kondisi bangunan (Created), yaitu mudah dipindahkan bangunannya, bahan bangunan seadanya dan dibangun sendiri oleh pemilik. Kedua, wilayah kumuh turunan (Generated), yaitu permukiman dahulunya dibangun dengan ijin yang jelas namun tidak terurus lama kelamaan menjadi wilayah kumuh atau rumah tersebut kumuh, daerah lama yang dikelilingi oleh pemekatan kota dan bangunan yang kuran terpelihara. Ketiga, wilayah kumuh dalam proyek perumahan (in project housing), yaitu berekonomi rendah yang menempati perumahan yang telah disediakan oleh badan pemerintahan dan diperluasnya rumah tanpa ijin dan kurangnya pemeliharaan.

Berdasarkan morfologinya dan berdasaarkan tiga point tersebut, terdapat enam kategori pemukiman kumuh, yaitu di ekitar industry, di daerah permukiman, memanjang samping rel kereta api, saluran pengatus dan jalan, di sekitaran kolam atau waduk, di daerah proyek perumahan dan di daerah pertanian. Morfologi permukiman kumuh menggunakan foto udara (Suharini, 2007) seperti terlihat pada Gambar 1.

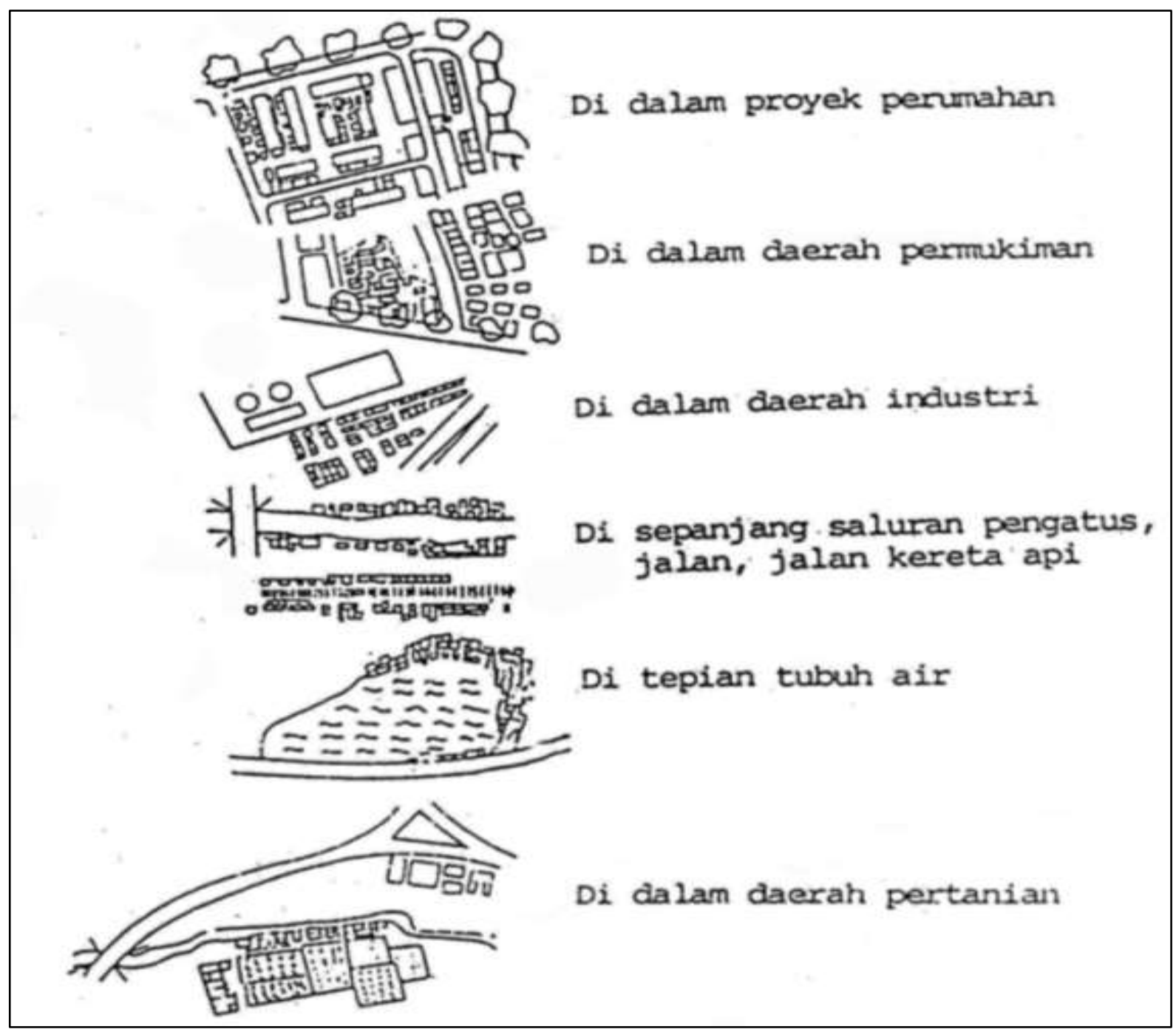

Gambar 1. Hasil Foto Udara Pemukiman Kumuh Hasil Interpretasi 
Permasalahan utama dalam kajian ini adalah terdapat permukiman kumuh di Kota Bandung, yang mengakibatkan Kota Bandung tidak teratur dan juga tidak bersih dan sehat, karena pada wilayah pemukiman kumuh kurangnya fasilitas kesehatan dan juga infrastruktur bangunan yang kurang layak huni.

Pemanfaatan teknologi penginderaan jauh untuk pemetaan pola sebaran spasial permukiman kumuh, khususnya di Kota Bandung jarang dilakukan. Kajian permukiman kumuh yang dikaji lebih banyak menekankan pada faktor penyebab keberadaan permukiman kumuh (Christiawan \& Budiarta, 2017; Ilmy \& Budisusanto, 2017) dan klasterisasi permukiman kumuh (Barbara \& Umilia, 2014; Setiadi, 2014). Penelitian dengan memanfaatkan teknologi penginderaan jauh dan sistem informasi geografis merupakan suatu strategi inovatif dalam memvisualisasikan secara spasial permasalahan yang ada sehingga menghasilkan informasi geospasial yang akurat. Mengingat pentingnya permasalahan permukiman kumuh untuk dikaji maka penelitian ini bertujuan untuk mengetahui persebaran rumah kumuh dan juga mengetahui pola persebaran rumah kumuh di Kota Bandung, supaya pemukiman kumuh dapat terpetakan dengan baik sehingga mudah untuk menanggulanginya.

\section{Metode}

Penelitian dilakukan di Kota Bandung, Jawa Barat. Yang luasnya sekitar 167,7 Km2. Metode yang digunakan menggunakan metode Interpretasi Visual pada citra yang berresolusi tinggi, menggunakan citra Quickbird dimana menganalisisnya menggunakan unsur - unsur Interpretasi seperti Rona, Warna, Ukuran, Tekstur, Pola, Bayangan, Situs dan Asosiasi (Suharini, 2007). Ada dua proses interpretasi citra diantaranya proses untuk menemukan arti pentingnya objek serta elemen dan proses perumusan identitas objek serta elemen yang di deteksi pada citra (sutanto 1986). Hasil dari prosesnya dikelompokan sesuai dengan kemiripannya, sehingga dapat dikatakan proses interpretasi citra adalah mengelompokan karakteristik atau fenomena di permukaan bumi berdasarkan kemiripan atau homogenitasnya membentuk pola tertentu.

Setelah menginterpretasi citra pada citra yang beresolusi tinggi Quickbird pada permukiman yang berdempetan, bisa dilihat dari ketidak adaannya air bersih atau juga lokasinya jauh dari air bersih dengan melihat sungai dan lain sebagainya dari citra tersebut, maka metode atau langkah selanjutnya untuk memastikannya yaitu dengan cara groundcek langsung ke lapangan dengan cara melihat langsung apakah betul atau tidak tempat tersebut kumuh dengan melihat kerapatan bangunan, tata letak dan kondisi bangunan dilokasi tersebut. Atau juga bisa di lihat dari kriteria variable prmukiman kumuh dan tidak kumuh seperti terlihat pada Tabel 1.

Tabel 1. Kriteria Variable Pemukiman Kumuh dan tidak kumuh

\begin{tabular}{|c|c|c|c|c|}
\hline \multirow{2}{*}{ No } & \multirow{2}{*}{\multicolumn{2}{|c|}{ Variable }} & \multicolumn{2}{|c|}{ Kriteria } \\
\hline & & & Kumuh & Tidak Kumuh \\
\hline \multirow{3}{*}{1} & \multirow{3}{*}{ Citra Satelit } & $\begin{array}{l}\text { Kerapatan } \\
\text { Rumah }\end{array}$ & $\begin{array}{l}\text { Sangat Padat, Padat, } \\
\text { Agak Padat }\end{array}$ & Tidak Padat / Jarang \\
\hline & & $\begin{array}{l}\text { Luas Atap / } \\
\text { Rumah }\end{array}$ & $\begin{array}{l}\text { Luas Rumah rata / blok } \\
>60 \mathrm{~m}^{2}\end{array}$ & $\begin{array}{l}\text { Luas Rumah rata / } \\
\text { blok }>60 \mathrm{~m}^{2}\end{array}$ \\
\hline & & Tata Letak & $\begin{array}{l}<20 \%, 20-60 \% \text { per blok } \\
\text { permukiman teratur }\end{array}$ & $\begin{array}{l}>60 \% \text { per blok } \\
\text { Pemukiman teratur }\end{array}$ \\
\hline \multirow{3}{*}{2} & \multirow{3}{*}{ Survey Lapangan } & $\begin{array}{l}\text { Kondisi } \\
\text { Bangunan }\end{array}$ & & Permanen \\
\hline & & $\begin{array}{l}\text { Kondisi } \\
\text { Lingkungan }\end{array}$ & Kotor & Bersih \\
\hline & & Tata Letak & $\begin{array}{l}\text { Pemukiman agak } \\
\text { teratur, tidak teratur }\end{array}$ & Pemukiman Teratur \\
\hline
\end{tabular}

Sumber: Suharini (2007) 


\section{Hasil dan Pembahasan}

Pada penelitian kali ini Pemukiman kumuh dapat dilihat dari citra resolusi tinggi, Quickbird 2007 dilihat dari penutup bangunan berupa atap dan kekontrasan bangunan sebagai berikut

1. Bangunan berupa atap

Atap bangunan pemukiman kumuh sangat terlihat jika dibandingkan dengan pemukiman tidak kumuh. Ketidak rataan warna atap atau penutup bangunan pemukiman kumuh sehingga mudah sekali membedakan mana pemukiman kumuh dan bukan pemukiman kumuh dilihat dari citra satelit resolusi tinggi Quickbird 2007 seperti terlihat pada Gambar 2.

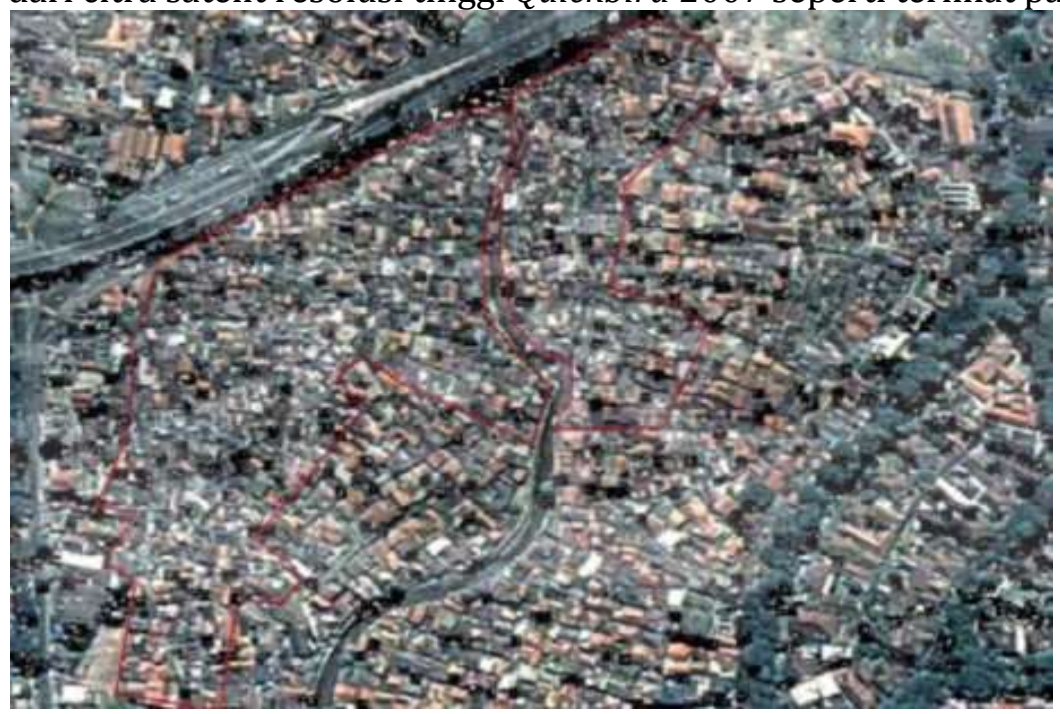

Gambar 2. Identifikasi pemukiman kumuh dilihat dari atap bangunan menggunakan citra Quickbird 2007 (Sumber: Auliannis, 2009)

Dilihat dari citra Quickbird 2007, atap pemukiman kumuh berbeda dengan atap pemukiman bukan kumuh karena pada pemukiman kumuh atap tidak teratur atau tidak tersusun rapih layaknya pemukiman tidak kumuh.

2. Kekontrasan bangunan

Kekontrasan warna pada atap bangunan sangat terlihat mana pemukiman kumuh dan tidak karena pemukiman yang tidak kumuh memiliki atap berupa genteng atau berwarna orange sedangkan pemukiman kumuh biasanya memiliki atap bukan orange melainkan abu-abu karena biasanya atap bangunan tersebut terbuat dari seng bukan genteng dan lain sebagainya seperti terlihat pada Gambar 3.

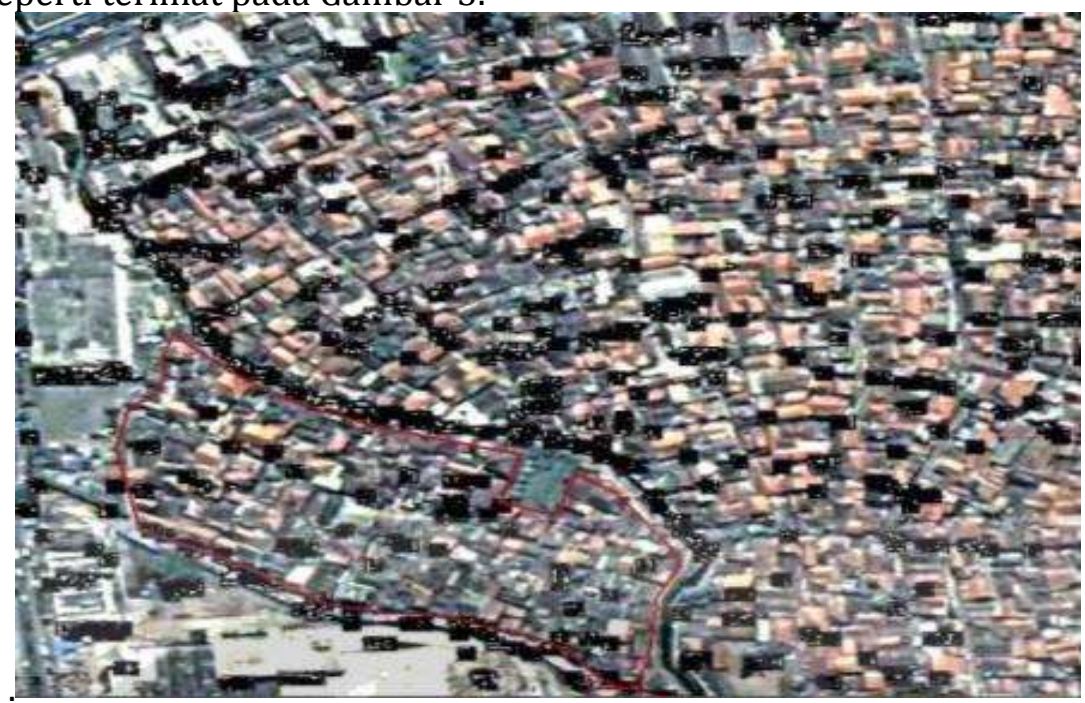

Gambar 3. Identifikasi pemukiman kumuh dilihat dari kekontrasan bangunan menggunakan citra Quickbird 2007 (Sumber: Auliannis, 2009) 
Dilihat dari citra Quickbird 2007, kekontrasan bangunan pemukiman kumuh berbeda dengan kekontrasan warna bangunan pemukiman bukan kumuh karena pada pemukiman kumuh warnanya tidak kontras dengan warna pemukiman di samping sampingnya. Pemukiman kumuh biasanya ber warna abu - abu dan biasanya di sepanjang sungai, waduk atau juga di sepanjang jalan kereta. Setelah melihat dari citra satelit Quickbird 2007 seperti di atas dapat di identifikasikan diantaranya kerapatan rumah atau bangunan, Tata letak, dan kondisi bangunan.

1. Kerapatan Rumah atau Bangunan

Deskripsi kerapatan rumah atau bangunan seperti terlihat pada Tabel 2.

Table 2. Identifikasi pemukiman kumuh dilihat dari kerapatan rumah atau bangunan hasil interfretasi menggunkan citra Quickbird 2007 serta Groundcek ke lapangan.

\begin{tabular}{|l|l|l|l|}
\hline No & Kerapatan Bangunan & Luas (Ha) & Persentase \\
\hline 1 & Rendah $(<68$ bang/ha) & 308.439 & 42,98 \\
\hline 2 & Sedang (68-105 bang/ha) & 349,669 & 47,71 \\
\hline 3 & Tinggi $(>105$ bang/ha) & 74,828 & 10.21 \\
\hline
\end{tabular}

Permukiman Kumuh dengan kerapatan bangunan Rendah memiliki presentase 42,08 \% atau dengan luas sebesar 308,439 ha. Sedangkan untuk kerapatan bangunan rendah di seluruh kecamatan Bojong Loa Kidul, Bandung Kidul, Bojongloa Kaler, Babakan Ciparay, dan Cibiru.

Permukiman Kumuh dengan kerapatan bangunan sedang memiliki presentase 47,71 \% atau dengan luas sebesar 349.669 ha. Sedangkan untuk kerapatan bangunan sedang di seluruh bantaran $\mathrm{Ci}$ teureup, $\mathrm{Ci}$ kapundung dan $\mathrm{Ci}$ beunying.

Permukiman kumuh Dengan Kerapatan Bangunan Tinggi Memiliki persentase 10,21\% atau Luas sebesar 74.828 ha Sedangkan untuk kerapatan bangunan tinggi seperti di kecamatan Bandung Wetan, coblong, cidadap, cicendo, Bojongloa Kaler, Sumur Bandung, sukajadi, Cibeunying Kidul, Cicadas, Batununggal, babakan ciparay, Cibeunying Kaler, dan Kiaracondong.

2. Tata Letak

Deskripsi tata letak bangunan seperti terlihat pada Tabel 3.

Table 3. Identifikasi pemukiman kumuh dilihat dari Tata letak hasil interfretasi menggunkan citra Quickbird 2007 serta Groundcek ke lapangan.

\begin{tabular}{|l|l|l|l|}
\hline No & Tata Letak & Luah (Ha) & Persentase (\%) \\
\hline 1 & $>60 \%$ Per Blok Pemukiman Teratur & 13.129 & 1.79 \\
\hline 2 & $20-60 \%$ Per Blok Pemukiman Teratur & 654.651 & 89.32 \\
\hline 3 & $<20 \%$ Per Blok Pemukiman Teratur & 65.156 & 8.89 \\
\hline
\end{tabular}

Permukiman kumuh dengan tata letak $>60 \%$ Per Blok Pemukiman Teratur, terdapat pada kecamatan Andir, Ujung Berung, dan Kiaracondong.

permukiman kumuh dengan tata letak 20-60\% Per Blok Pemukiman Teratur, terdapat pada kecamatan Bojong Loa kaler, Regol, Bojongloa Kidul, Margacinta, Babakan Ciparay, dan Rancsari Bandung Kidul.

Permukiman kumuh dengan tata letak $<60 \%$ Per Blok Pemukiman Teratur, terdapat pada kecamatan Sukajadi, Cicendo, Cidadap, Coblong, Bandung Kulon, Batununggal, dan Kiaracondong.

3. Kondisi Bangunan

Deskripsi kondisi bangunan seperti terlihat pada Tabel 4. 
Table 4. Identifikasi pemukiman kumuh dilihat dari kondisi bangunan hasil interfretasi menggunkan citra Quickbird 2007 serta Groundcek ke lapangan.

\begin{tabular}{|l|l|l|l|}
\hline No & Kondisi Bangunan & Luas (ha) & Persentase (\%) \\
\hline 1 & Kontruksi Bangunan tidak permanen $<30 \%$ & 317.789 & 43.36 \\
\hline 2 & $\begin{array}{l}\text { Kontruksi Bangunan tidak permanen 30-60\% } \\
\text { (semi permanen) }\end{array}$ & 404.348 & 55.17 \\
\hline 3 & Kontruksi Bangunan tidak permanen $>60 \%$ & 10.799 & 1.47 \\
\hline
\end{tabular}

Permukiman kumuh dengan Kontruksi Bangunan tidak permanen $<30 \%$ terdapat pada kecamatan Bandung Kidul, Sukajadi, margacinta, Babakan Ciparay, dan Bojongloa Kidul. Permukiman kumuh dengan Kontruksi Bangunan tidak permanen 30-60\% terdapat pada kecamatan Bandung Kulon, Kiaracondong, Batununggal, dan Bojongloa Kaler.

Permukiman kumuh dengan Kontruksi Bangunan tidak permanen $>60 \%$ terdapat pada kecamatan Babakan Ciparay, Batununggal, Cicendo, Coblong, dan Cidadap.

Setelah mengidentifikasi pemukiman kumuh menggunakan citra Quickbird 2007. Dengan melihat dari unsur unsur interpretasi citra seperti Rona, Ukuran, Warna, Tekstur, Bayangan, Pola, Asosiasi, dan Situs. Didukung dengan Groundchek langsung ke lapangan untuk memastikannya bahwa data hasil interpretasi tersebut betul atau tidaknya. Luasan pemukiman kumuh seperti terlihat pada Tabel 5.

Tabel 5 . Kategori Kepadatan penduduk dilihat dari luas dan presentasenya

\begin{tabular}{|c|l|r|r|}
\hline No & \multicolumn{1}{|c|}{ Kepadatan Penduduk } & Luas (Ha) & Persentase (\%) \\
\hline 1 & Rendah & 15.747 & 2.15 \\
\hline 2 & Sedang & 80.37 & 10.97 \\
\hline 3 & Tinggi & 636.809 & 86.88 \\
\hline
\end{tabular}

Sumber : Auliannis, 2009

Dilihat dari table tersebut hasil dari interpretasi citra yang didukung dengan groundchek ke lapangan pemukiman kumuh terendah dengan persentase $2.15 \%$ atau dengan luasan 15.747ha terdapat di wilayah Cicadas, Regol, Sukajadi, dan Babakan Ciparay. Sedangkan kategori pemukiman kumuh sedang dengan persentase 10.97 atau luasan 80.37ha terdapat di wilayah Margacinta, Sukajadi dan Regol. Dan juga kategori pemukiman kumuh tinggi dengan persentase 86.88\% atau dengan luasan 636.809ha terdapat di wilayah Bandung Kulon, Kiara Condong, Coblong, dan Bojongloa Kaler.

Dilihat dari Variable di atas bahwa di setiap kecamatan terdapat pemukikan kumuh yang sebagian besar berletak di pinggir jalan utama, pasar, pinggir sungai dan kolektor seperti terlihat pada Tabel 6 .

Table 6. Luas atau Presentase Pemukiman Kumuh Perkecamatan .

\begin{tabular}{|l|l|l|l|}
\hline No & Kecamatan & Luas (Ha) & Persentase (\%) \\
\hline Wilayah Pengembangan Bojonegara & 88.385 & 12.06 \\
\hline 1 & Andir & 12.872 & 1.76 \\
\hline 2 & Cicendo & 29.888 & 4.08 \\
\hline 3 & Sukajadi & 45.625 & 6.22 \\
\hline Wilayah Pengembangan Cibeunying & 111.461 & 15.21 \\
\hline 4 & Bandung Wetan & 10.75 & 1.47 \\
\hline 5 & Cibeunying Kaler & 32.764 & 4.47 \\
\hline 6 & Cibeunying Kidul & 17.472 & 2.38 \\
\hline 7 & Cidadap & 20.951 & 2.86 \\
\hline 8 & Coblong & 26.79 & 3.65 \\
\hline 9 & Sumur Bandung & 2.734 & 0.37 \\
\hline Wilayah Pengembangan Gede Bage & 159.363 & 21.74 \\
\hline
\end{tabular}




\begin{tabular}{|c|c|c|c|}
\hline 10 & Bandung Kidul & 13.592 & 1.85 \\
\hline 11 & Margacinta & 102.304 & 13.96 \\
\hline 12 & Rancasari & 44.955 & 6.13 \\
\hline \multicolumn{2}{|c|}{ Wilayah Pengembangan Kares } & 98.876 & 13.49 \\
\hline 13 & Batununggal & 27.666 & 3.77 \\
\hline 14 & Kiaracondong & 33.624 & 4.59 \\
\hline 15 & Lengkong & 3.924 & 0.54 \\
\hline 16 & Regol & 33.662 & 4.59 \\
\hline \multicolumn{2}{|c|}{ Wilayah Pengembangan Tegalega } & 201.137 & 27.44 \\
\hline 17 & Astana Anyar & 1.97 & 0.27 \\
\hline 18 & Babakan Ciparay & 78.312 & 10.68 \\
\hline 19 & Bandung Kulon & 42.131 & 5.75 \\
\hline 20 & Bojong Loa Kaler & 37.486 & 5.11 \\
\hline 21 & Bojong Loa Kidul & 39.75 & 5.42 \\
\hline \multicolumn{2}{|c|}{ Wilayah Pengembangan Ujung Berung } & 73.714 & 10.06 \\
\hline 22 & Arcamanik & 14.028 & 1.91 \\
\hline 23 & Cibeunying Kidul & 0.934 & 0.13 \\
\hline 24 & Cibiru & 8.403 & 1.15 \\
\hline 25 & Cicadas & 35.653 & 4.86 \\
\hline 26 & Ujung Berung & 14.696 & 2.00 \\
\hline \multicolumn{2}{|c|}{ Total } & 732.936 & 1.00 \\
\hline
\end{tabular}

Sumber : Auliannis, 2009

Dapat dilihat dari tabel hasil penelitian tersebut bahwa luas area pemukiman kumuh seluas 732.936 ha. Dengan luas pemukiman terkecil di wilayah pengembangan Ujung Berung, dan kategori terbesar pada wilayah Tegallega. Setelah melakukan penelitian dapat terpetakan pemukiman kumuh sebagai berikut. Peta hasil persebaran rumah kumuh di kota Bandung seperti terlihat pada Gambar 4.

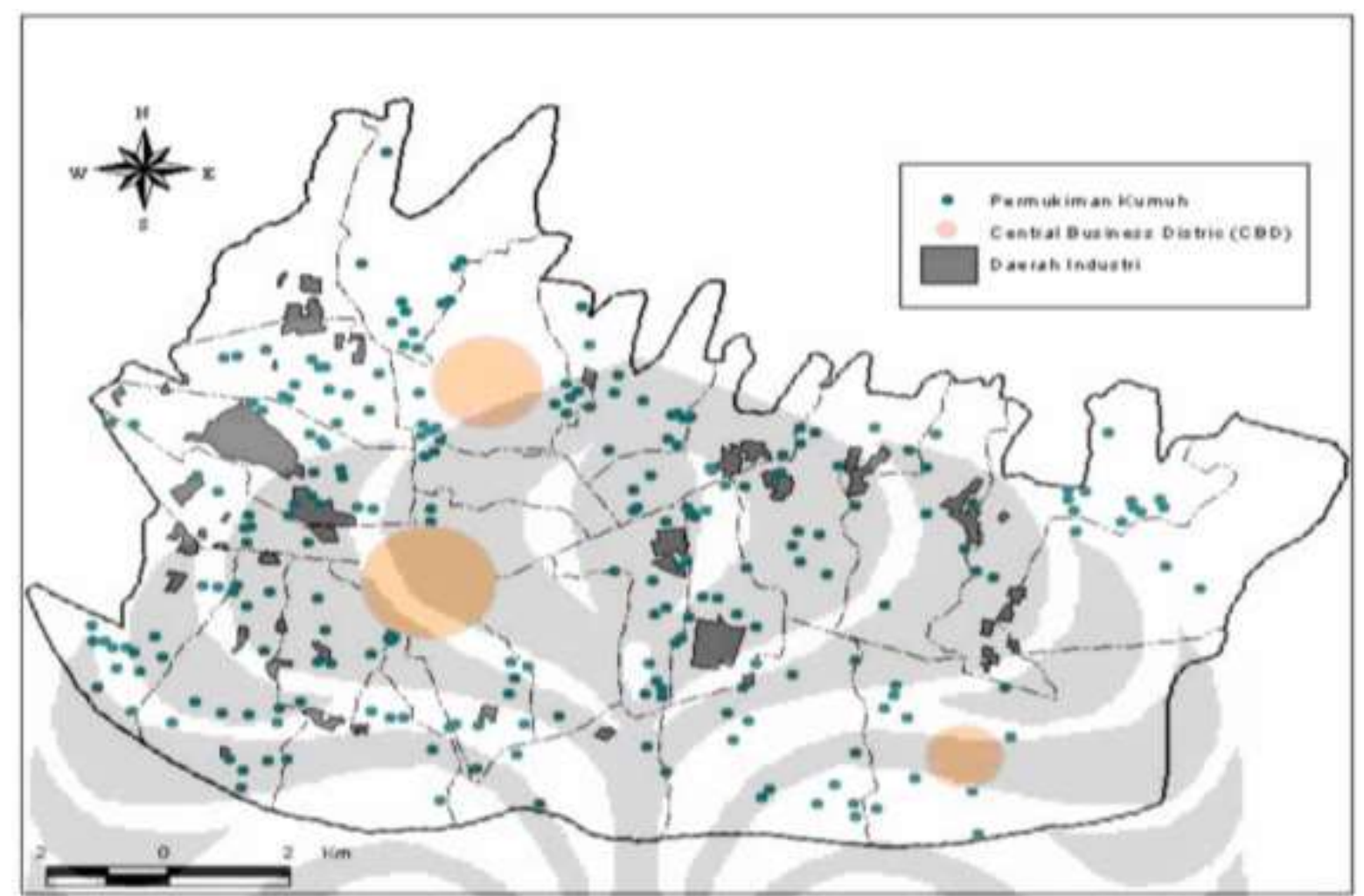

Gambar 4. Peta Hasil Persebaran Rumah Kumuh Di Kota Bandung 
Dapat dilihat dari peta diatas bahwa secara umum keberadaan pemukiman kumuh di Kota Bandung lebih mengelompok dan berada di wilayah pusat kegiatan atau central business district (CBD). Padan dasarnya CBD atau Daerah Pusat Kegiatan (DPK) adalah bagian kecil dari kota yang merupakan pusat dari segala kegiatan politik, social, budaya, ekonomi, dan teknologi. CBD merupakan zona dengan derajat aksesibilitas tinggi pada suatu kota. Kawasan CBD merupakan pusat komersial dan bisnis di sebuah kota (Indrawati, Hartono, \& Sunarto, 2016). Di kota-kota besar, CBD merupakan kawasan finansial karena di sanalah transaksi keuangan dengan skala besar terjadi. Umumnya, CBD pada sebuah kota memiliki properti ritel dan perkantoran dalam jumlah yang siginifikan, serta memiliki kepadatan lebih tinggi dibanding kawasan lain di kota tersebut. Kawasan ini merupakan daerah perindustrian dan pusat primer kota bandung. Karena pada daerah pusat kota banyak sekali penduduk bukan asli orang bandung akan tetapi perantau yang berdagang atau juga karyawan lalu bertinggal tetap di central business district (CBD) dan wilayah industri. Kajian ini sejalan dengan hasil penelitian Maru \& Hidayat (2016) yang memperlihatkan bahwa tingkat kenyamanan permukiman dipengaruhi oleh keberadaan CBD.

\section{Simpulan dan Saran}

Setelah melakukan penelitian terhadap rumah kumuh di kota bandung dapat ditarik kesimpulan bahwa peningkatan pemukiman di kota bandung sangat cepat karena banyaknya masyarakat yang migrasi. Pola persebaran rumah kumuh di daerah bandung sebagian besar membentuk pola tersebar (Scattern Pattern) terdapat di daerah Tegallega dan Ujung Berung yang cenderung mendekati daerah industri. pola acak (Radom Patten) dan cenderung mendekati daerahdaerah pusat kegiatan seperti jasa, perkantoran dan industri. Yang terdapat di wilayah pengembangan cibeunying, gede bage, dan pengembangan karees. Sedangkan Pola mengelompok (Cluster Pattern) terdapat diwilayah pengembangan Bojonegara dan pengembangan karees, yang cenderung mendekati daerah jasa dan perdagangan.

Adapun saran untuk menangulangi pemukiman kumuh yaitu kepekaan masyarakat untuk mengajukan bantuan kepada kepemerintahan untuk menanggulangi dengan cara memperbaiki rumah kumuh menjadi rumah layak huni. karena sekarang terdapat anggaran untuk rumah tidak layak huni atau rutilahu. atau juga kepekaan pemerintahan terhadap rumah kumuh atau tidak layak huni yang bertempat tinggal menurut kriteria pemukiman kumuh yaitu sepanjang rel kereta api, sepanjang sungai dan lain sebagainya. Untuk menanggulangi pemukiman kumuh yang bersebaran di kota Bandung yang dapat menggangu kebersihan dan kenyamanan kota.

\section{Daftar Rujukan}

Auliannis, D. (2009). Pemukiman Kumuh Di Kota Bandung. Depok: Universitas Indonesia.

Barbara, P. B., \& Umilia, E. (2014). Clustering Permukiman Kumuh di Kawasan Pusat Kota Surabaya. Jurnal Teknik Pomits, 3(2), 172-177.

Christiawan, P. I. (2019a). Designing The Mitigation Model Of Urban Sprawl Potential Impact In Suburban Denpasar, Bali. Journal of Physics: Conference Series, 1363(1), 1-7. https://doi.org/10.1088/1742-6596/1363/1/012100

Christiawan, P. I. (2019b). Tipe Urban Sprawl dan Eksistensi Pertanian di Wilayah Pinggiran Kota Denpasar. Jurnal Wilayah Dan Lingkungan, 7(2).

Christiawan, P. I., \& Budiarta, I. G. (2017). Entitas Permukiman Kumuh Di Wilayah Pesisir. Jurnal Ilmu Sosial Dan Humaniora, 6(2), 178-187.

Ekatarji, P., Yunus, H. S., \& Rahardjo, N. (2016). Kajian Kualitas Lingkungan Permukiman di Daerah Pinggiran Kota Kasus di Desa Ngestiharjo, Yogyakarta. Majalah Geografi Indonesia, 28(1), 96-102.

Ilmy, F. H., \& Budisusanto, Y. (2017). Identifikasi Penentuan Prioritas Kriteria Kawasan Permukiman Kumuh Perkotaan Menggunakan Metode AHP (Analytical Hierarcy Process). Jurnal Teknik ITS, 6(1), 19-21.

Indrawati, L., Hartono, H., \& Sunarto, S. (2016). Klasifikasi Pohon keputusan untuk Kajian Perubahan Penggunaan lahan Kota Semarang Menggunakan Citra Landsat TM.ETM+. Majalah Geografi Indonesia, 23(2), 109-123. 
Isunju, J. B., Schwartz, K., Schouten, M. A., Johnson, W. P., \& van Dijk, M. P. (2011). Socio-economic aspects of improved sanitation in slums: A review. Public Health, 125(6), 368-376. https://doi.org/10.1016/j.puhe.2011.03.008

Maru, A. C. H., \& Hidayat, I. N. (2016). Pemanfaatan itra Quickbird dan SIG untuk Pemetaan Tingkat Kenyamanan permukiman di Kecamatan Semarang Barat Utara. Majalah Geografi Indonesia, 30(1), 1-8.

Muhammad, B. A., \& Sulistyarso, H. (2016). Arahan Penataan Lingkungan Permukiman Kumuh Kecamatan Kenjeran dengan Pendekatan Eco-Settlements. Jurnal Teknik ITS, 5(2), 124-128.

Setiadi, A. (2014). Tipologi Dan Pola Penanganan Permukiman Kumuh Di Kota Bontang. Tata Loka, 16(4), 220-233.

Simon, R. F., Adegoke, A. K., \& Adewale, B. A. (2013). Slum Settlements Regeneration in Lagos Mega-city: an Overview of a Waterfront Makoko Community. International Journal of Education and Research, 1(3), 1-16.

Sintiawati, I. G. A. P. M. S., Wesnawa, I. G. A., \& Suditha, I. N. (2014). Karakteristik dan Proses Terbentuknya Permukiman Kumuh di Wilayah Pesisir Desa Sangsit (Kasus Desa Sangsit). Jurnal Jurusan Pendidikan Geografi, 5(1), 1-10. Retrieved from http://ejournal.undiksha.ac.id/index.php/JJPG/article/view/3734

Suharini, E. (2007). Menemukenali Agihan Permukiman Kumuh Di Perkotaan Melalui Interpretasi Citra Pengindraan Jauh. Semarang: Universitas Negeri Semarang. 